\title{
Foraging behaviour and habitat selection of the little penguin Eudyptula minor during early chick rearing in Bass Strait, Australia
}

\author{
Andrew J. Hoskins ${ }^{1, *}$, Peter Dann ${ }^{2}$, Yan Ropert-Coudert ${ }^{3}$, Akiko Kato ${ }^{4}$, \\ André Chiaradia ${ }^{2}$, Daniel P. Costa ${ }^{5}$, John P. Y. Arnould ${ }^{1}$ \\ ${ }^{1}$ School of Life and Environmental Sciences, Deakin University, 221 Burwood Highway, Burwood, Victoria 3125, Australia \\ ${ }^{2}$ Research Department, Phillip Island Nature Park, PO Box 97, Cowes, Victoria 3922, Australia \\ ${ }^{3}$ Centre National de la Recherche Scientifique, Institut Pluridisciplinaire Hubert Curien, Département Ecologie, \\ Physiologie et Ethologie, UMR 7178 CNRS-ULP, 23, rue Becquerel, 67087 Strasbourg Cedex 02, France \\ ${ }^{4}$ National Institute of Polar Research, 1-9-10 Kaga, Itabashi-ku, Tokyo 173-8515, Japan \\ ${ }^{5}$ Center for Ocean Health, University of California, 100 Shaffer Road, Santa Cruz, California 95060, USA
}

\begin{abstract}
Knowledge of the foraging areas of top marine predators and the factors influencing them is central to understanding how their populations respond to environmental variability. While there is a large body of literature documenting the association of air-breathing marine vertebrates with areas of high marine productivity, there is relatively little information for species restricted to near-shore or continental-shelf areas. Differences in foraging range and diving behaviour of the little penguin Eudyptula minor were examined from 3 breeding colonies (Rabbit Island, Kanowna Island and Phillip Island) in central northern Bass Strait, southeast Australia, during the chick-guard stage using electronic tags (platform terminal transmitters, PTTs, and time-depth recorders, TDRs). Although there were large overall differences between individuals, the mean maximum foraging range $(16.9$ to $19.8 \mathrm{~km})$ and mean total distance travelled $(41.8$ to $48.0 \mathrm{~km}$ ) were similar between the 3 colonies, despite different bathymetric environments. Individuals from all 3 colonies selected foraging habitats within a narrow sea surface temperature (SST) range $\left(16.0\right.$ to $\left.16.4^{\circ} \mathrm{C}\right)$. While there were significant differences in mean dive depths $(5.4$ to $10.9 \mathrm{~m})$ and mean durations (13.2 to $28.6 \mathrm{~s}$ ) between the different colonies, the mean diving effort (vertical distance travelled: 936.3 to $964.3 \mathrm{~m}$ $\mathrm{h}^{-1}$ ) was similar. These findings suggest little penguins from the 3 colonies employ relatively similar foraging efforts yet are plastic in their foraging behaviours.
\end{abstract}

KEY WORDS: Compositional analysis $\cdot$ Diving $\cdot$ Coastal ecosystem $\cdot$ Nearshore habitats $\cdot$ Sea surface temperature $\cdot$ Seabird

Resale or republication not permitted without written consent of the publisher

\section{INTRODUCTION}

The marine environment is an ecosystem of constant flux, where unpredictable or cyclical changes cause areas of primary productivity to be patchy and generally impermanent (Hansen et al. 2001). In response, marine predators, such as seabirds, marine mammals, fish and turtles, concentrate their foraging efforts in areas where prey are abundant due to high primary production as a result of upwelling or are more concentrated or predictable due to physical forcing associated with fronts and eddies (Polovina et al. 2001). However, during the breeding season, seabirds and pinnipeds are forced to adopt a central place foraging strategy (Orians \& Pearson 1979), as they need to return to shore to feed their young. Limitations in the available breeding habitat and the fasting capabilities of their young restrict foraging time and range, leaving 
many predictable prey patches out of reach (Hunt et al. 1992). While distribution of marine predators relative to oceanographic features has received considerable attention (e.g. Ainley et al. 1998), the fine-scale habitat utilisation and behaviours associated with these features is still largely unknown (Costa \& Sinervo 2004).

While the foraging behaviours of many seabird species have been documented, most such studies have involved individuals from a single colony or, if at more than 1 site, several colonies in different years (e.g. Perriman et al. 2000). Until recently, relatively few studies have investigated inter-colony variability in foraging behaviour within a breeding season, removing the confounding effect of inter-annual variability in between-colonies comparisons (Peck \& Congdon 2005, Wilson et al. 2005). Consequently, for many studies, it is not possible to determine whether the behaviours observed are colony-specific, due to inter-annual variability, or reflect those of the species in general.

At the lower end of the size range of marine endotherms, the little penguin Eudyptula minor offers unique insight into the constraints faced by marine predators. This penguin breeds on offshore islands from the southwest coast of Western Australia, across the southern coast (including Tasmania) and up the eastern coast of mainland Australia as far north as South Solitary Island, and on to New Zealand and the Chatham Islands in the east (Marchant \& Higgins 1990). It is the smallest species of penguin, averaging $30 \mathrm{~cm}$ in height and $1 \mathrm{~kg}$ in body mass, giving it a reduced swimming speed when compared to other penguin species (Bethge et al. 1997). This, coupled with the limited fasting and thermoregulatory capabilities of its chicks (foraging trips during the chick-guard phase of breed-

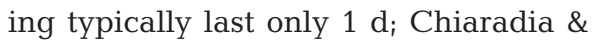
Nisbet 2006) means that, during breeding, little penguins have a restricted foraging range in comparison to most seabirds (Dann \& Norman 2006). Consequently, many areas of large-scale primary productivity (fronts, eddies and upwellings) are out of reach during the guard phase of the breeding season.

The movements at sea and diving behaviours of little penguins have been documented at several locations and have shown variation both between colonies and between years (Weavers 1992, Collins et al. 1999, Chiaradia et al. 2007). However, the aforementioned studies were conducted in different years, using a variety of methods such that it is difficult to make inferences about the behavioural responses of little penguins to different foraging conditions. Furthermore, while bathymetry has been found to have an effect on the diving behaviour of little penguins (Chiaradia et al. 2007), there is no published information on other environmental factors influencing habitat selection for this species in marine environments. Indeed, there is currently limited information on the physical factors influencing the habitat choice of inshore/coastal foraging seabirds in general (Oedekoven et al. 2001, Paiva et al. 2008). Such knowledge is crucial for understanding how these species may respond to environmental perturbations, both natural and man-made.

The aims of this study, therefore, were to (1) determine foraging range and diving depths in little penguins during guard phase; (2) investigate environmental factors that might influence these parameters; and (3) assess their intra- and inter-colonial variation in foraging behaviour.

\section{MATERIALS AND METHODS}

Study sites and field procedures. The study was conducted during the chick-guard stage of the 20052006 breeding season on 3 offshore islands in the central northern Bass Strait, southeast Australia (Fig. 1): Rabbit Island $\left(38^{\circ} 54^{\prime} \mathrm{S}, 146^{\circ} 31^{\prime} \mathrm{E}\right)$; Kanowna Island $\left(39^{\circ} 09^{\prime} \mathrm{S}, 146^{\circ} 18^{\prime} \mathrm{E}\right) ;$ and Phillip Island $\left(38^{\circ} 31^{\prime} \mathrm{S}\right.$, $\left.154^{\circ} 08^{\prime} \mathrm{E}\right)$. Bass Strait is an on-shelf region of highly

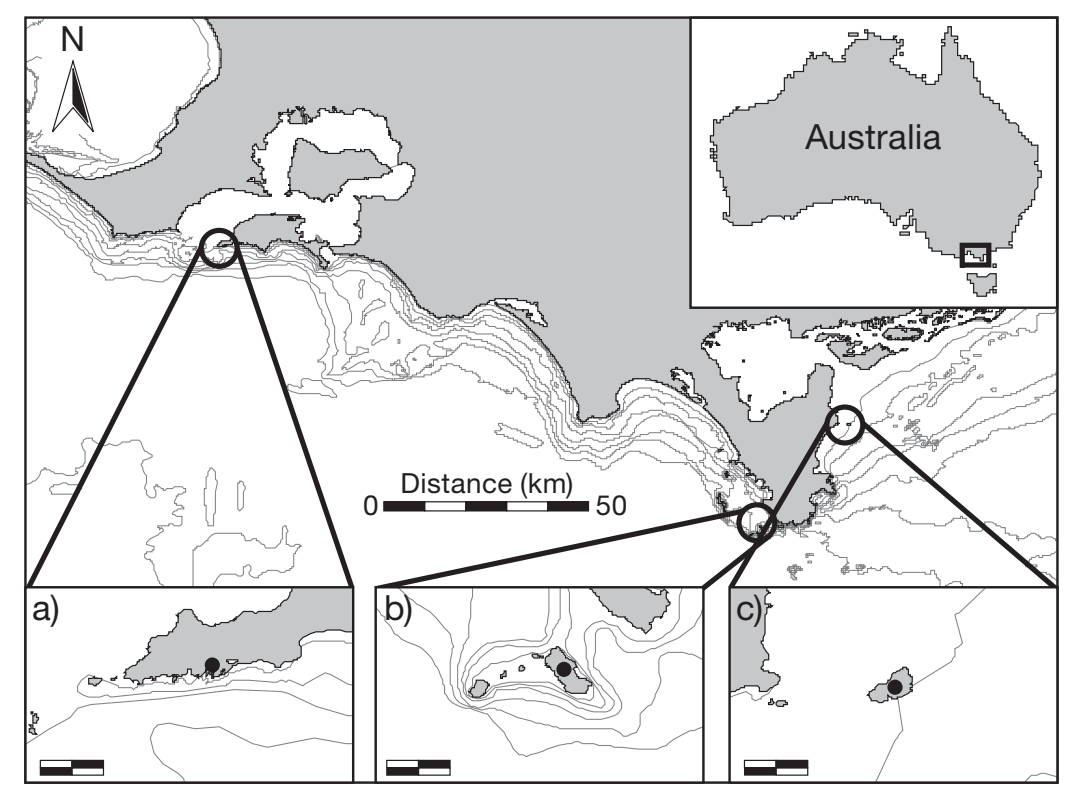

Fig. 1. Location of the 3 study colonies (indicated by black circles) in central northern Bass Strait: Phillip Island (a); Kanowna Island (b); and Rabbit Island (c). Bathymetry contours in $10 \mathrm{~m}$ intervals and scale bars represent $1 \mathrm{~km}$ unless otherwise indicated 
mixed water recognised for its relatively low marine productivity (Gibbs et al. 1986, Sandery \& Kampf 2005). Individuals foraging within this area would not encounter any substantial fronts, upwellings or eddies (Gibbs et al. 1986, Gibbs 1992). The estimated sizes of the little penguin breeding colonies on these islands are: Rabbit Island, 2000 individuals; Kanowna Island, 2100 individuals; and Phillip Island, 26000 individuals (P. Dann unpubl. data).

Rabbit Island (Fig. 1c) (26.8 ha) is a small, granite, tussock-covered island off the northeastern coast of Wilsons Promontory, Victoria. Individuals from this colony encounter a shallow bathymetry, characterised by a gently sloping seafloor extending many $\mathrm{km}$ from the island. Kanowna Island (Fig. 1b) (32.9 ha) is a small, granite, tussock-covered island located off the southern tip of Wilsons Promontory. In comparison to Rabbit Island, individuals from this colony encounter a deeper bathymetry with a very steep southerly sloping seafloor, which quickly reaches depths of $80 \mathrm{~m}$. Phillip Island (Fig. 1a) (10056.4 ha) is located at the mouth of Western Port. Individuals from this colony encounter a bathymetry that is intermediate between Rabbit Island and Kanowna Island, with a moderately sloping seafloor. The 3 islands were selected in part for their bathymetric surroundings and logistical constraints determining which colonies could be feasibly sampled within the same breeding season.

Information on the foraging areas and behaviour of individuals was collected using 2 different types of externally attached instruments. At-sea locations were recorded using hydrodynamically shaped platform terminal transmitters $(\mathrm{PTT} ; \times 2 \times 1.5 \mathrm{~cm}, 32$ g; Kiwisat 202, Sirtrack Wildlife Tracking Solutions). Diving behaviour was recorded using cylindrically shaped miniature electronic time-depth recorders (TDR; $4.8 \times 1.5 \mathrm{~cm}$, $14 \mathrm{~g}$; UME-190DT, Little Leonardo) programmed to record depth $( \pm 0.1 \mathrm{~m})$ every second. Both instruments had a cross-sectional surface area $<5 \%$ of the total body cross-sectional surface area of the individuals and, hence, would have had a minimal impact on foraging behaviour (Wilson et al. 1986).

Individuals were captured in their burrows during daylight hours and weighed in a cloth bag on a spring scale $( \pm 0.05 \mathrm{~kg})$, sexed by bill depth (Arnould et al. 2004) and their breeding status recorded. Identification of individuals was achieved through passive induction transponders (PIT tag, $11 \times 1.5 \mathrm{~mm}$, Trovan) injected subcutaneously posterior to the scapula at first capture. Suitable individuals, determined as being individuals rearing chicks less than 3 wk of age (chickguard stage), were then instrumented with a single device only once during the chick-guard stage of breeding (chicks $<2 \mathrm{wk}$ old). The predictable foraging trip duration $(1 \mathrm{~d})$ during this stage provides an ideal period to compare the responses of individuals to environmental conditions without the potentially confounding factor of variable trip durations. Devices were attached to the dorsal midline, $3 \mathrm{~cm}$ anterior to the base of the tail using waterproof cloth tape (Tesa 4651) following the methods of Ropert-Coudert et al. (2003). Upon returning from a single foraging trip, instrumented individuals were recaptured in their burrows and the devices were removed by carefully peeling the tape away.

Data analyses. We filtered erroneous locations out of the uplinks from the PTTs using the 3-stage filtering algorithm of Austin et al. (2003), developed in the R statistical environment (R-Development Core Team 2003). Criteria for the algorithm were based upon the 90th percentile of travel speeds and distances $\left(2 \mathrm{~m} \mathrm{~s}^{-1}\right.$ and $9 \mathrm{~km}$, respectively) for all Argos class 0, 1, 2 and 3 locations. The filtered locations were then analysed using the timeTrack software package (version 1.5, M. D. Sumner, University of Tasmania, Hobart) in the R statistical environment (R-Development Core Team 2003). To give sufficient weighting to areas where the greatest proportion of the foraging trip was spent, routes were interpolated (frequency $5 \mathrm{~min}$ ) from the filtered locations assuming a constant and shortest route between 2 locations. A foraging trip was defined as the moment an individual departed from its colony until the moment it returned. However, due to the low frequency of satellite fixes, departure/arrival times had to be estimated based on the mean travel speed from the individual's trip and the distance from the nearest location to land. Several characteristics of each foraging trip were then determined: mean bearing from colony $\left({ }^{\circ}\right)$; range of bearings $\left({ }^{\circ}\right.$ ) per individual (to determine the spread of the foraging trip); total distance travelled $(\mathrm{km})$; and maximum straight-line distance in water (i.e. not crossing land) from the colony ( $\mathrm{km})$.

Previous studies of marine top-level predators have shown 3 oceanographic variables (sea surface temperature, sea-surface chlorophyll a [chl a] concentration and bathymetry) to be important in the foraging choices of these animals (Yen et al. 2004, Pinaud et al. 2005). Hence, these 3 factors were investigated in regards to habitat characteristics and marine habitat selection of little penguins. Sea-surface temperature (SST) and surface chl a concentration data (during the times of deployment, 9 Nov until 18 Dec 2005, 1 km² resolution) were extracted in $8 \mathrm{~d}$ averages from the Moderate Resolution Imaging Spectroradiometer (MODIS) satellite data base (NASA, Washington, DC, USA). Missing pixels were interpolated using nearest-neighbour inversedistance weighted (IDW) interpolation (ArcView 3.3 with Spatial Analyst extension, ESRI GIS and Mapping Software). Bathymetric data were obtained in $0.01^{\circ}$ grid resolution from Geoscience Australia (Canberra, Aus- 
tralia) and plotted in $10 \mathrm{~m}$ contour intervals. Oceanographic variables (bathymetry, SST and surface chl a concentration) were then extracted at each of the interpolated points and foraging trip means were calculated. Differences in modes of foraging were then investigated using the foraging trip characteristics and oceanographic variables.

The degree of habitat selection was determined for the 3 colonies using the methods of Aebischer et al. (1993). Briefly, the analysis uses a combination of multivariate analysis of variance (MANOVA) and multiple analysis of covariance (MANCOVA) models to assess the degree to which a type of habitat is used. Proportions of used versus available habitat are determined to differ significantly from what would be expected when the variance differs considerably than what would be expected by random chance. Each oceanographic variable was divided into a number of interval classes: bathymetry $(10 \mathrm{~m}), \operatorname{SST}\left(0.2^{\circ} \mathrm{C}\right)$ and surface chl a concentration $\left(0.4 \mathrm{mg} \mathrm{m}^{-3}\right)$. Available habitat was determined by calculating the at-sea area encompassed by a radius of the maximum distance a little penguin has been recorded to travel during a $1 \mathrm{~d}$ foraging trip (36 km, present study). The proportions of each available habitat class for all 3 variables were then determined within this area.

Individual foraging routes were overlayed on a $1 \mathrm{~km}^{2}$ grid of this area and the grid cells traversed were marked as used. The used grid cells for each individual were then overlayed with the bathymetry, SST and surface chl a concentration classes and the proportions of each available habitat used were calculated. Comparisons of the habitat classes used in relation to the available habitats were undertaken using compositional analysis (Aebischer et al. 1993) using the Compos Analysis package Version 6.2 (Smith Ecology) with 1000 iterations per analysis to obtain an alpha $<0.05$.

Data from the TDRs were downloaded and processed using a custom-built macro written in Igor Pro v. 5.0 (Wavemetrics) to obtain depth, duration, bottom time, ascent and descent rates, and the post-dive interval for each dive. From these data, the mean and maximum dive depth and dive duration, vertical distance travelled per hour of daylight, trip duration (taken as the start of the first dive $>1 \mathrm{~m}$ to the end of the last dive $>1 \mathrm{~m}$ ), and the total number of dives were calculated for each individual. Individual dive profiles were visually examined and dive shapes recorded using custom-built software written in Labview 4 (National Instruments) and the classification methods of Schreer et al. (2001) modified to include
2 extra dive types (U shaped pelagic/demersal dives and W shaped pelagic dives, cf. Tremblay \& Cherel 2000 ) in addition to the 4 categories (V, left and right skewed V, and square shaped benthic/demersal) used by Schreer et al. (2001).

Statistical analyses followed the methods of Quinn \& Keough (2002) using SPSS Version 12.0 (SPSS), unless otherwise indicated. All data are presented as mean $\pm \mathrm{SE}$.

\section{RESULTS}

\section{Foraging areas}

At-sea movement data were obtained from 20, 20 and 21 individuals from Rabbit, Kanowna and Phillip islands, respectively, producing a total of 1457 unfiltered locations, which, once filtered, was reduced to 577 locations (Fig. 2). Individuals from each colony foraged in discrete areas to maximum distances from their respective colony of 5.6 to $36.0 \mathrm{~km}$ while travelling total distances of 17.7 to $80.4 \mathrm{~km}$. Summary statistics of the foraging trips of individuals from the 3 colonies are shown in Table 1.

There was a significant difference in body mass between the sexes of instrumented individuals but no significant differences between the colonies (2-way ANOVA; sex: $F_{1,61}=36.6, \mathrm{p}<0.001$; colony: $F_{2,61}=0.3$, $\mathrm{p}=0.716)$. Despite the sex difference in mass, there were no significant differences in any of the foraging trip characteristics or oceanographic variables encountered between the 2 sexes (MANOVA, p > 0.05 in all cases). However, significant differences were found at the colony level, with individuals from all colonies encountering different depths (MANOVA with Tukey's post hoc test, $\left.F_{2,61}=323.4, \mathrm{p}<0.001\right)$. A significant difference was also found in the mean bearings

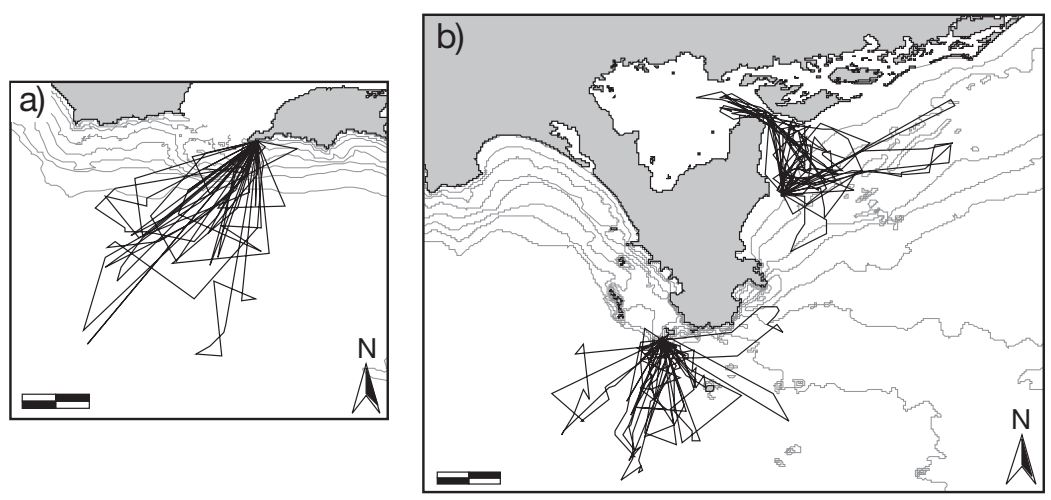

Fig. 2. Eudyptula minor. Foraging trip routes of individuals from Phillip Island $(\mathrm{a}, \mathrm{n}=21)$, Kanowna Island ( $\mathrm{b}, \mathrm{n}=20$ ) and Rabbit Island $(\mathrm{b}, \mathrm{n}=20)$. Bathymetry contours are in $10 \mathrm{~m}$ intervals and scale bars represent $10 \mathrm{~km}$ 
Table 1. Eudyptula minor. A summary of foraging trip characteristics at 3 colonies in central northern Bass Strait

\begin{tabular}{|lcccccccc|}
\hline Colony & $\begin{array}{c}\text { Mass } \\
(\mathrm{g})\end{array}$ & $\begin{array}{c}\text { Max } \\
\text { dist. }(\mathrm{km})\end{array}$ & $\begin{array}{c}\text { Total } \\
\text { dist. }(\mathrm{km})\end{array}$ & $\begin{array}{c}\text { Mean } \\
\text { bearing }\left({ }^{\circ}\right)\end{array}$ & $\begin{array}{c}\text { Bearing } \\
\text { range }\left({ }^{\circ}\right)\end{array}$ & $\begin{array}{c}\text { Seabed depth } \\
(\mathrm{m})\end{array}$ & $\begin{array}{c}\text { SST } \\
\left({ }^{\circ} \mathrm{C}\right)\end{array}$ & $\begin{array}{c}\text { Chl } a \\
\left(\mathrm{mg} \mathrm{m}^{-3}\right)\end{array}$ \\
\hline $\begin{array}{l}\text { Rabbit Island } \\
(10 \text { female, 10 male })\end{array}$ & $1084 \pm 24$ & $18.3 \pm 1.4$ & $48.0 \pm 2.7$ & $127 \pm 22$ & $75 \pm 9$. & $10.2 \pm 2.0$ & $16.0 \pm 0.2$ & $0.94 \pm 0.05$ \\
$\begin{array}{l}\text { Kanowna Island } \\
(10 \text { female, 10 male })\end{array}$ & $1084 \pm 24$ & $16.9 \pm 1.3$ & $41.8 \pm 2.5$ & $177 \pm 7$ & $67 \pm 12$ & $68.1 \pm 6.6$ & $16.2 \pm 0.0$ & $0.22 \pm 0.01$ \\
$\begin{array}{l}\text { Phillip Island } \\
(10 \text { female, 11 male })\end{array}$ & $1076 \pm 17$ & $19.8 \pm 1.8$ & $45.2 \pm 3.9$ & $208 \pm 4$ & $38 \pm 7$ & $55.8 \pm 28.5$ & $16.2 \pm 0.8$ & $0.40 \pm 0.01$ \\
\hline
\end{tabular}

(MANOVA with Tukey's post hoc test), with Rabbit Island individuals travelling in a different direction (average bearing: $127^{\circ}$ ) from Kanowna Island (average bearing: $177^{\circ}$ ) and Phillip Island (average bearing: $208^{\circ}$ ) individuals. The mean bearing range was also significantly lower (MANOVA with Tukey's post hoc test, $F_{2,61}=3.4, \mathrm{p}=0.045$ ) for Phillip Island, indicating that individuals from this colony ranged over a smaller arc than those from the other 2 colonies.

\section{Habitat selection}

Results of the compositional analysis showed that individuals from each colony significantly selected specific bathymetric classes. Rabbit Island individuals selected the $0-20 \mathrm{~m}$ depth class (Wilks' $\lambda=0.0045$, $\chi^{2}{ }_{4}=108.2, \mathrm{p}<0.001$, range available: 0 to $80 \mathrm{~m}$ ), while individuals from Kanowna Island (Wilks' $\lambda=0.0010$, $\chi_{4}^{2}=138.1, \mathrm{p}<0.001$, range available: 0 to $80 \mathrm{~m}$ ) and Phillip Island (Wilks' $\lambda=0.0069, \chi^{2}{ }_{7}=104.4, \mathrm{p}<0.001$, range available: 0 to $80 \mathrm{~m}$ ) selected the depth classes 60-80 $\mathrm{m}$ and $20-30 \mathrm{~m}$, respectively.

Habitat use by individuals from Rabbit Island was found to differ significantly from random with respect to surface chl a concentration (Wilks' $\lambda=0.0165, \chi^{2}{ }_{14}=$ 82.1, $\mathrm{p}<0.005$, range available: 0 to $8.0 \mathrm{mg} \mathrm{m}^{-3}$ ). Significant selection, however, was found across a broad range of classes, from 0.0 to $4.8 \mathrm{mg} \mathrm{m}^{-3}$ (12 habitat classes). Individuals from Kanowna Island had a monomorphic habitat available with regards to surface chl a concentration; thus compositional analysis could not be conducted. Phillip Island individuals were found to forage in areas with surface chl a concentrations of 0.4 to $0.8 \mathrm{mg} \mathrm{m}^{-3}$ significantly more than random (Wilks' $\lambda=0.0030, \chi^{2}{ }_{3}=122.2, \mathrm{p}<0.001$, range available: 0 to $8.0 \mathrm{mg} \mathrm{m}^{-3}$ ).

Whereas the bathymetry and surface chl a concentration classes selected by individuals differed between the colonies, habitat selection with regards to SST was remarkably consistent across all 3 sites. Individuals from Rabbit Island favoured areas with a SST class of 16.0 to $16.2^{\circ} \mathrm{C}$ (Wilks' $\lambda=0.0057, \chi^{2}{ }_{3}=103.2$, $\mathrm{p}<0.01$, range available: $13.8-18.6^{\circ} \mathrm{C}$ ), whereas areas with SST of $16.2-16.4^{\circ} \mathrm{C}$ were selected the most by individuals from Kanowna Island (Wilks' $\lambda=0.0001, \chi^{2}{ }_{3}$ $=154.2, \mathrm{p}<0.001$, range available: 15.8 to $17.2^{\circ} \mathrm{C}$ ) and Phillip Island (Wilks' $\lambda=0.0006, \chi^{2}{ }_{4}=126.9, \mathrm{p}<0.001$, range available: $15.0-18.6^{\circ} \mathrm{C}$ ) (Fig. $3 \mathrm{a}-\mathrm{f}$ ).

\section{Diving behaviour}

Diving behaviour data were obtained from 9 Rabbit Island (5 female, 4 male), 8 Kanowna Island (5 female, 3 male), and 10 Phillip Island (5 female, 5 male) individuals. Individual mean and maximum dive depths ranged from 4.0 to $15.6 \mathrm{~m}$ and 17.4 to $50.7 \mathrm{~m}$, respectively, while individual mean and maximum dive durations ranged from 8.0 to $40.0 \mathrm{~s}$ and 37.0 to $92.0 \mathrm{~s}$, respectively (Table 2).

There were no significant differences in the mass of individuals instrumented with TDRs between sexes or between colonies (2-way ANOVA; p > 0.05 in both cases). However, in addition to the significant differences in mean dive depth, maximum dive depth, mean dive duration and the total number of dives between the colonies (MANOVA, $\mathrm{p}<0.003$ in all cases), there were significant differences in mean dive depth, mean dive duration and maximum dive duration between the sexes (MANOVA, p $<0.005$ in all cases). Males dived for both longer average and maximum durations, and to deeper average depths than females (MANOVA with Tukey's post hoc test, mean dive duration, $\mathrm{p}<0.005$ in all cases).

Individuals from Phillip Island dived to greater average depths than those from Rabbit Island, with individuals from Kanowna Island diving the shallowest (MANOVA with Tukey's post hoc test, $F_{2,27}=17.164$, $\mathrm{p}<0.001$, Table 2). Individuals from Rabbit Island performed significantly shallower dives as indicated by maximum dive depths than either Kanowna Island or Phillip Island (MANOVA with Tukey's post hoc test, $F_{2,27}=17.415, \mathrm{p}<0.001$, Table 2). Individuals from Kanowna Island performed more dives of significantly shorter average durations than individuals from either 

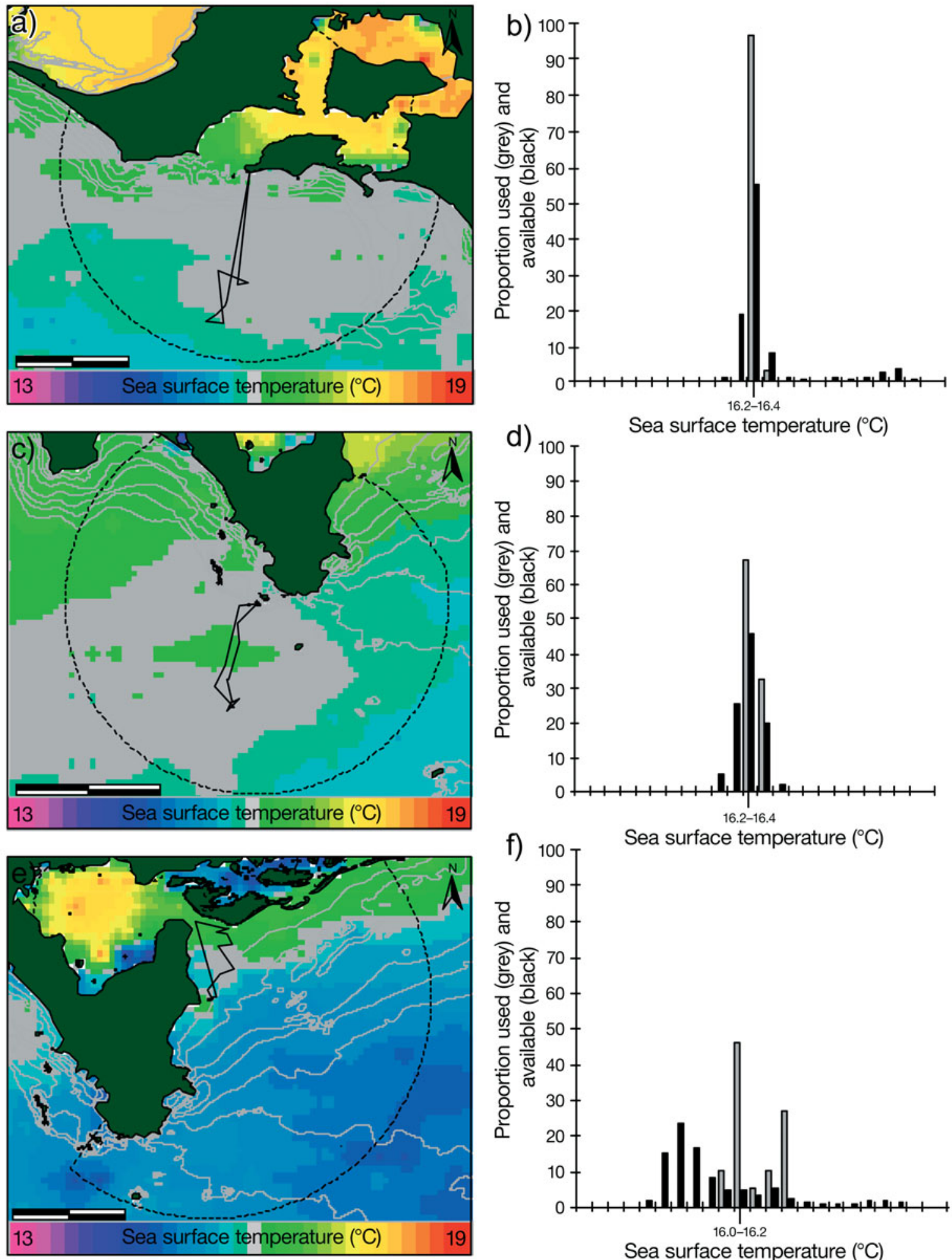

Fig. 3. Eudyptula minor. Relationship between representative foraging trip routes of little penguins from Phillip Island (a, b), Kanowna Island (c, d) and Rabbit Island (e, f) and SST. Graphs b, d and f show the percentages of used (grey) versus available (black) SST with the selected temperatures indicated. Bathymetry contours are in $10 \mathrm{~m}$ intervals, SST is in $0.2^{\circ} \mathrm{C}$ intervals with the most significantly selected SST highlighted in grey (see text for details). Distance scales represent 10km. Available foraging area marked with a dashed line 
Table 2. Eudyptula minor. Summary of the diving behaviour data collected from little penguins at 3 colonies in central northern Bass Strait with significance levels shown at the bottom. Asterisks represent homogenous subsets

\begin{tabular}{|c|c|c|c|c|c|c|c|c|}
\hline \multirow[t]{2}{*}{ Colony } & \multirow{2}{*}{$\begin{array}{l}\text { Mass } \\
(\mathrm{g})\end{array}$} & \multicolumn{2}{|c|}{ Dive depth (m) } & \multicolumn{2}{|c|}{ Dive duration (s) } & \multirow{2}{*}{$\begin{array}{l}\text { Trip duration } \\
\text { (h) }\end{array}$} & \multirow{2}{*}{$\begin{array}{l}\text { Vertical distance } \\
\text { travelled }\left(\mathrm{m} \mathrm{h}^{-1}\right)\end{array}$} & \multirow{2}{*}{$\begin{array}{l}\text { No. of } \\
\text { dives }\end{array}$} \\
\hline & & Mean & Max & Mean & $\operatorname{Max}$ & & & \\
\hline \multicolumn{9}{|l|}{ Rabbit Island } \\
\hline Female $(\mathrm{n}=5)$ & $1032 \pm 39$ & $7.5 \pm 0.3$ & $23.7 \pm 1.4$ & $24.6 \pm 1.6^{*}$ & $62.4 \pm 3.4$ & $14.7 \pm 0.4$ & $910.6 \pm 77.6$ & $902.0 \pm 80.3$ \\
\hline Male $(\mathrm{n}=4)$ & $1137 \pm 61$ & $8.9 \pm 0.1$ & $21.6 \pm 1.8$ & $33.5 \pm 1.4$ & $70.8 \pm 2.2$ & $14.6 \pm 0.1$ & $1031.4 \pm 67.8$ & $855.8 \pm 67.4$ \\
\hline Total & $1078 \pm 37$ & $8.1 \pm 0.4$ & $22.7 \pm 1.1$ & $28.6 \pm 3.0$ & $66.1 \pm 2.5$ & $14.7 \pm 0.2$ & $964.3 \pm 53.7$ & $881.4 \pm 51.2^{*}$ \\
\hline \multicolumn{9}{|l|}{ Kanowna Island } \\
\hline Female $(\mathrm{n}=5)$ & $984 \pm 54$ & $4.3 \pm 0.4$ & $33.1 \pm 2.3$ & $10.6 \pm 2.0$ & $69.8 \pm 5.5$ & $15.1 \pm 0.1$ & $890.5 \pm 117.2$ & $1582.8 \pm 190.2$ \\
\hline Male $(\mathrm{n}=3)$ & $1086 \pm 34$ & $7.1 \pm 0.3$ & $37.2 \pm 3.0$ & $17.4 \pm 2.5$ & $84.67 \pm 3.8$ & $15.0 \pm 0.1$ & $1012.4 \pm 155.3$ & $1101.3 \pm 105.0$ \\
\hline Total & $1022 \pm 39$ & $5.4 \pm 0.8$ & $34.6 \pm 1.8^{*}$ & $13.2 \pm 4.4$ & $75.3 \pm 4.2$ & $15.1 \pm 0.1$ & $936.3 \pm 89.4$ & $1402.4 \pm 147.9$ \\
\hline \multicolumn{9}{|l|}{ Phillip Island } \\
\hline Female $(\mathrm{n}=5)$ & $1054 \pm 57$ & $9.1 \pm 0.4$ & $37.1 \pm 5.5$ & $23.0 \pm 2.6$ & $66.2 \pm 7.4$ & $14.8 \pm 0.1$ & $901.0 \pm 83.4$ & $863.2 \pm 242.9$ \\
\hline Male $(\mathrm{n}=5)$ & $1097 \pm 32$ & $12.83 \pm 0.9$ & $45.8 \pm 3.0$ & $34.1 \pm 5.1$ & $84.4 \pm 1.6$ & $15.38 \pm 0.2$ & $1010.3 \pm 138.4$ & $606.8 \pm 75.7$ \\
\hline Total & $1073 \pm 31$ & $10.9 \pm 1.4$ & $41.4 \pm 3.3^{*}$ & $28.5 \pm 7.7^{*}$ & $75.3 \pm 4.7$ & $15.1 \pm 0.2$ & $955.6 \pm 78.3$ & $735.0 \pm 127.3^{*}$ \\
\hline $\mathrm{p}_{\mathrm{sex}}$ & 0.06 & $<0.01$ & 0.21 & $<0.01$ & $<0.01$ & 0.66 & 0.21 & 0.5 \\
\hline $\mathrm{p}_{\text {colony }}$ & 0.62 & $<0.01$ & $<0.01$ & $<0.01$ & 0.09 & 0.09 & 0.983 & $<0.01$ \\
\hline
\end{tabular}

Rabbit Island or Phillip Island (MANOVA with Tukey's post hoc test, $\mathrm{p}<0.001$ in both cases, Fig. 4c,d). There was no significant difference between the sexes or between the colonies for any of the other dive behaviour variables measured ( $p>0.05$ in all cases).

With the exception of $\mathrm{V}$ shaped dives, there were significant differences in the proportions of all dive types between the colonies (MANOVA, $p<0.001$ in all cases). The foraging trips of Rabbit Island and Phillip Island individuals consisted of a greater proportion of U shaped dives $(73.5 \pm 3.6 \%$ and $67.5 \pm 3.2 \%$, respectively) but lower proportions of $\mathrm{W}, \mathrm{V}$, left skewed and right skewed dives than those of Kanowna Island individuals (Fig. 4). Square-shaped benthic dives were a minor proportion in the foraging trips of individuals from Rabbit Island $(3.5 \pm 0.7 \%)$ yet still significantly more common than in the foraging trips of individuals from the other colonies where they were rarely observed ( $<1 \%$ in both cases) (Fig. 4).

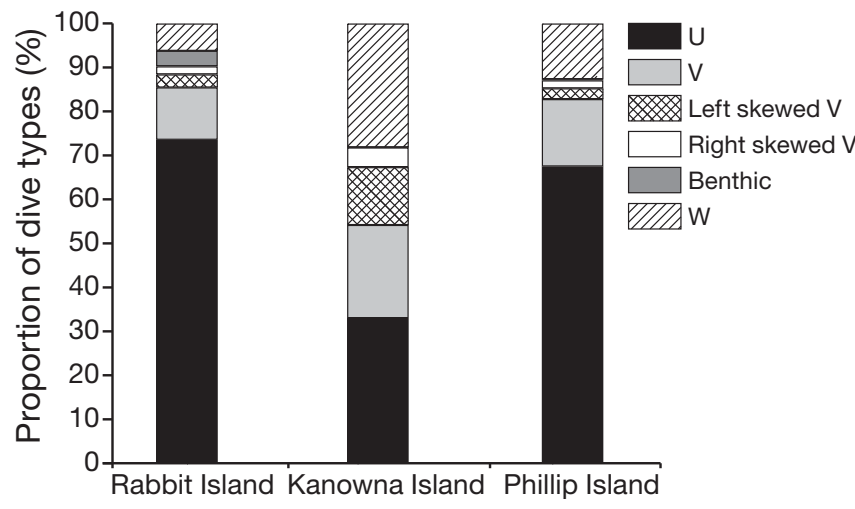

Fig. 4. Eudyptula minor. Proportion of the 6 observed dive types in little penguins from 3 colonies in the northern Bass Strait

\section{DISCUSSION}

Foraging areas

Weavers (1992) showed that little penguins foraging during years of lowered prey availability responded by increasing their foraging ranges, presumably to increase their search areas and prey encounter rates. In the present study, the maximum distances travelled were substantially greater than those previously recorded for $1 \mathrm{~d}$ foraging trips (Weavers 1992, Collins et al. 1999), suggesting that little penguins experienced lower prey availability than during previous studies (Weavers 1992). Alternatively, the differences observed between the studies could have arisen through differences in methodology, with earlier studies relying on radio-tracking where, although attached transmitters are smaller, the technique is much less applicable for tracking free-ranging animals over large distances. Comparisons of the present and previous studies, therefore, highlight the importance of multi-year information on the foraging areas of marine higher-predators for ecosystem management and policy development (e.g. Marine Protected Areas, fisheries quotas etc.).

Contrary to the results of studies on other seabirds (Kato et al. 2000), no sexual differences were found in any of the foraging area variables recorded. In penguin species where sex differences in foraging range have been observed, these have been associated with differences in foraging trip duration (Clarke et al. 1998). It is possible, however, that during the chickguard stage in little penguins, sex differences in foraging range are not apparent due to the restrictions of a $1 \mathrm{~d}$ foraging trip strategy.

In the present study, there were no differences in the foraging ranges of individuals from the 3 colonies stud- 
ied despite differences in environmental conditions (surface chl $a$ and bathymetry) encountered in the areas in which they foraged. It is unlikely these differences in environmental conditions reflected differences in prey type between the colonies, as extensive analyses of little penguin diets at numerous sites over several years within Bass Strait indicate that the overwhelming majority of prey consumed is consistently Clupeiforme fish (pilchards, anchovies and sandy sprat; Cullen et al. 1992, Chiaradia et al. 2003, Hoffmann 2006). Concurrent studies during the chickguard period of the 2005-2006 breeding season showed the diet at Rabbit Island and Phillip Island consisted primarily of pilchards $(12.3 \%$ and $0 \%)$ and anchovies (58\% and 30\%) (Hoffmann 2006, Chiaradia et al. unpubl. data).

Embayment habitats such as Western Port and Corner Inlet are known to be important nurseries for local fish species (Hoedt et al. 1995, Jenkins et al. 1997). Correspondingly, it is possible that little penguins from Rabbit Island were targeting juvenile fish in this region. Individuals from Phillip Island had potential access to similar embayment habitat within their foraging range (Western Port); however, no individuals tracked from this colony were recorded foraging there. Little penguins have been recorded foraging in Western Port in the past, in low numbers, particularly in autumn (Dann et al. 2001), when the availability of clupeoids appears to be greatest (Hoedt et al. 1995). Hoedt et al. (1995) also found that only juveniles or small adult pilchards and anchovies were found within Western Port and it is possible little penguins from Phillip Island could be ignoring these for larger more energy dense adults aggregated outside the bay (Hobday 1992, Tirelli et al. 2006).

\section{Habitat selection}

In the present study, the results of compositional analysis determined that habitat selection was apparent for both sea surface chl $a$ and bathymetry, but these were not consistent between the 3 colonies and are likely to have been influenced by local factors. In contrast, there was strong selection for SST $\left(16.0\right.$ to $\left.16.4^{\circ} \mathrm{C}\right)$ common across the 3 colonies. Stahel \& Nicol (1982) found that little penguins displayed no thermoneutral zone in water, with metabolic rate increasing only gradually from $30^{\circ} \mathrm{C}$ to $10^{\circ} \mathrm{C}$ before increasing dramatically. Consequently, it is unlikely selection for such a narrow range of SST reflects thermoregulatory abilities restricting the foraging areas of little penguins but, rather, influences of prey distribution and availability.

Marine apex predators concentrate foraging activity in regions characterised by particular oceanographic features that enhance primary productivity and prey availability (Daunt et al. 2003). Bathymetric gradients, surface chl a concentrations and sea surface temperature all influence prey to varying degrees both individually and in combination. For example, couplings between all 3 of these variables cause the concentration of prey that typically occurs in upwelling regions (Fiedler et al. 1991). While commonly there is a coupling between differences in SST and heightened chl a concentrations (e.g. oceanic fronts, Gangopadhyay \& Robinson 2002), this was not the case in the present study.

Temperature associations have been documented in other species of penguins; for example, King penguins have strong associations with the polar frontal zone (Jouventin et al. 1994), an area with strong SST gradients. Although these studies show large-scale associations with SST there is little information on penguins associations with fine-scale SST variations. However, the provisioning rate and amount of food fed to the chicks of wedge-tailed shearwaters Puffinus pacificus and sooty terns Sterna fuscata are affected by smallscale daily variations in SST around their breeding colonies, with researchers suggesting the link between fine-scale SST variations and prey distribution was the result of prey favouring specific temperatures for physiological reasons (Peck et al. 2004, Erwin \& Congdon 2007). If such a temperature preference exists in the prey of little penguins, it is understandable that they would forage within temperatures that are favoured by their prey. Interestingly, during the $2 \mathrm{wk}$ of tracking at Kanowna Island, only once was a bird tracked heading in a northerly direction. This was also the time when the available selected SST range also moved in a northerly direction, further suggesting a causal link between SST, prey distribution and little penguin habitat use.

Little is known of the factors that influence the distribution of the main prey of little penguins (pilchards and anchovies) within Bass Strait (Hobday 1992). However, Hobday (1992) observed a reduced abundance of pilchards and anchovies in the areas surrounding Phillip Island during years of higher-than-average SST. In addition, a related species, the Argentine anchovy Engraulis anchoita, favours waters of high thermal gradients and specific temperatures that vary between years (Hansen et al. 2001). Furthermore, Takasuka \& Aoki (2006) found that SST was more important than food abundance to the growth rates of larval Japanese anchovy Engraulis japonicus. These observations, therefore, imply that SST independent of $\mathrm{chl}$ a could influence the local distribution of Clupeifomes within Bass Strait. Indeed, Mickelson et al. (1992) suggested the observed coupling between higher-than-average SST in the western Bass Strait 
during winter months and delayed mean laying dates for little penguins at Phillip Island is mediated by the influence of SST on prey distribution.

\section{Diving behaviour}

The foraging behaviour of any aquatic air-breathing vertebrate is governed by the distribution of its prey within the water column and its diving abilities (Costa 1991). In the present study, sexual differences were found in diving behaviour (mean dive depth, mean and maximum dive duration). Previous studies have suggested that sexual size dimorphism can result in differences in diving behaviour (Kato et al. 2000, Yorke 2003). Although, in general, little penguins exhibit a slight sexual size dimorphism (Agnew \& Kerry 1995), in the present study, no difference was found between the body mass of males and females instrumented with TDRs. On land, male little penguins possess lower metabolic rates than females (Baudinette et al. 1986). If this is also true at sea it is possible this allows for a lower rate of oxygen consumption while diving, in turn allowing male little penguins to dive longer and achieve greater depths. In conjunction with the sexual differences found, the mean dive depths and durations of little penguins observed in the present study were significantly different between the 3 colonies. While information on the diet of little penguins in the present study was not available for all colonies, previous studies suggest little variation in prey type between colonies (Cullen et al. 1992, Hoffmann 2006). Consequently, the observed inter-colonial differences in dive behaviour may reflect differences in spatial distribution and availability of the same prey types between colonies.

Furthermore, the shape of dive profiles can provide information on the vertical distribution of prey and the hunting strategy of the predator (Schreer et al. 2001). In the present study, in addition to differences in dive depth and duration, there were differences in the dive profiles for individuals from the various colonies. The interspersing of square shaped benthic/demersal dives within series of $U$ shaped dives to similar depths at Rabbit Island suggests those penguins are targeting demersal prey. In contrast, individuals from Kanowna Island had the lowest proportion of U shaped dives and the highest proportions of mid-water pelagic foraging dives (W and V shaped), suggesting that their prey inhabits primarily the upper regions of the water column. Individuals from Phillip Island made the deepest dives and had a similar proportion of $U$ shaped dives to individuals from Rabbit Island but had a higher proportion of $\mathrm{W}$ shaped dives. This is consistent with the main prey of little penguins being found in all areas of the water column (Hobday 1992) and highlights the plasticity of foraging behaviours of the species in relation to differences in the distribution of their main prey. Similar findings have been reported in the little penguin and Magellanic penguin Spheniscus magellanicus where individuals from colonies with divergent local oceanographic conditions displayed markedly different diving behaviour to consume similar prey (Radl \& Culik 1999, Chiaradia et al. 2007).

Despite the differences in the number of dives, dive depths, dive durations and dive profiles, there were no significant differences between the colonies in the vertical distance travelled during daylight (an index of foraging effort, Boyd et al. 1991). This, coupled with there being no difference in the observed mean or maximum distances between the colonies, suggests that individuals from the 3 sites, and possibly little penguins in general, are quite energetically constrained in their foraging behaviours. Similar results have been discovered in gentoo penguins foraging in the Kerguelen archipelago, where individuals from multiple sites were found to display differing diving behaviours while still exhibiting similar diving efforts (Lescroel \& Bost 2005).

\section{CONCLUSION}

The results of the present study demonstrate the ability of little penguins to adapt their foraging behaviours to differing vertical distributions of prey while still being limited by similar energetic constraints. Individuals displayed differences in their diving behaviour in relation to the oceanographic features they encountered, while exploiting similar prey (Montague \& Cullen 1988, Hoffmann 2006). The consistent narrow range of SST selected by individuals from the 3 colonies further suggests strong relationships between SST and the little penguin's prey (Mickelson et al. 1992) but these relationships may work at a much finer scale than previously thought. These findings highlight the complex nature of the marine environments exploited by coastal/ near-shore foraging seabirds (Ray 1991).

Acknowledgements. For assistance in the field, we thank L. Renwick, J. McInnes, J. Hoffmann, E. Bogatyreva, J. Paplinska, R. Kirkwood, P. Fallow and several research volunteers at the Phillip Island Nature Park. Data analysis would not have been possible without the advice of S. B. Luque and M. D. Sumner. This project was supported financially by research grants from Toyota, Coast Care, National Oceanographic Partnership Program-ONR, National Polar Institute of Research, Japan and BHP-Billiton. All experiments were carried out in accordance with ethics permits from the Phillip Island Nature Park Animal Ethics Committee and a research permit from the Department of Sustainability and Environment. 


\section{LITERATURE CITED}

Aebischer NJ, Robertson PA, Kenward RE (1993) Compositional analysis of habitat use from animal radio-tracking data. Ecology 74:1313-1325

Agnew DJ, Kerry K (1995) Sexual dimorphism in penguins. In: Dann P, Norman FI, Reilly P (eds) The penguins: ecology and management. Beatty and Sons, Surrey, p 299-318

Ainley DG, Jacobs SS, Ribic CA, Gaffney I (1998) Seabird distribution and oceanic features of the Amundsen and southern Bellingshausen seas. Antarct Sci 10:111-123

Arnould JPY, Dann P, Cullen JM (2004) Determining the sex of little penguins (Eudyptula minor) in northern Bass Strait using morphometric measurements. Emu 104:261-265

Austin D, McMillan JI, Bowen WD (2003) A three-stage algorithm for filtering erroneous Argos satellite locations. Mar Mamm Sci 19:371-383

Baudinette RV, Gill P, Odriscoll M (1986) Energetics of the little penguin, Eudyptula minor, temperature regulation, the calorigenic effect of food and molting. Aust J Zool 34:35-45

Bethge P, Nicol S, Culik BM, Wilson RP (1997) Diving behaviour and energetics in breeding little penguins (Eudyptula minor). J Zool 242:483-502

Boyd IL, Lunn NJ, Barton T (1991) Time budgets and foraging characteristics of lactating Antarctic fur seals. J Anim Ecol 60:577-592

Chiaradia A, Nisbet ICT (2006) Plasticity in parental provisioning and chick growth in little penguins in years of high and low breeding success. Ardea 94:257-270

> Chiaradia A, Costalunga A, Kerry K (2003) The diet of little penguins (Eudyptula minor) at Phillip Island, Victoria, in the absence of a major prey-Pilchard (Sardinops sagax). Emu 103:43-48

Chiaradia A, Ropert-Coudert Y, Kato A, Mattern T, Yorke J (2007) Diving behaviour of little penguins from four colonies across their whole distribution range: bathymetry affecting diving effort and fledging success. Mar Biol 151: $1535-1542$

- Clarke J, Manly B, Kerry K, Gardner H, Franchi E, Corsolini S, Focardi S (1998) Sex differences in Adelie penguin foraging strategies. Polar Biol 20:248-258

Collins M, Cullen JM, Dann P (1999) Seasonal and annual foraging movements of little penguins from Phillip Island, Victoria. Wildl Res 26:705-721

Costa DP (1991) Reproductive and foraging energetics of high-latitude penguins, albatrosses and pinnipedsimplications for life-history patterns. Am Zool 31:111-130

> Costa DP, Sinervo B (2004) Field physiology: physiological insights from animals in nature. Annu Rev Physiol 66: 209-238

Cullen JM, Montague TL, Hull C (1992) Food of little penguins Eudyptula minor in Victoria - comparison of 3 localities between 1985 and 1988. Emu 91:318-341

> Dann P, Norman I (2006) Population regulation in little penguins Eudyptula minor: the role of intra specific competition for nesting sites and food during breeding. Emu 106: 289-296

Dann P, Jessop R, Healy M (2001) The distribution and abundance of little penguins at sea in Western Port, Victoria. The Victorian Naturalist 118:230-235

> Daunt F, Peters G, Scott B, Gremillet D, Wanless S (2003) Rapid-response recorders reveal interplay between marine physics and seabird behaviour. Mar Ecol Prog Ser 255:283-288

Erwin CA, Congdon BC (2007) Day-to-day variation in seasurface temperature reduces sooty tern Sterna fuscata foraging success on the Great Barrier Reef, Australia. Mar
Ecol Prog Ser 331:255-266

Fiedler PC, Philbrick V, Chavez FP (1991) Oceanic upwelling and productivity in the eastern tropical Pacific. Limnol Oceanogr 36:1834-1850

- Gangopadhyay A, Robinson AR (2002) Feature-oriented regional modeling of oceanic fronts. Dyn Atmos Oceans 36:201-232

Gibbs CF (1992) Oceanography of Bass Strait-implications for the food supply of little penguins Eudyptula minor. Emu 91:395-401

> Gibbs CF, Tomczak M, Longmore AR (1986) The nutrient regime of Bass Strait. Aust J Mar Freshwater Res 37: 451-466

> Hansen JE, Martos P, Madirolas A (2001) Relationship between spatial distribution of the Patagonian stock of Argentine anchovy, Engraulis anchoita, and sea temperatures during late spring to early summer. Fish Oceanogr 10:193-206

Hobday DK (1992) Abundance and distribution of Pilchard and Australian anchovy as prey species for the little penguin Eudyptula minor at Phillip Island, Victoria. Emu 91: 342-354

Hoedt FE, Dimmlich WF, Dann P (1995) Seasonal variation in the species and size composition of the clupeoid assemblages in Western Port, Victoria. Mar Freshw Res 46: 1085-1091

Hoffmann J (2006) The diet and foraging movements of little penguins (Eudyptula minor) at Rabbit Island, Victoria. Honours thesis, Monash University, Melbourne

> Hunt GL, Priddle J, Whitehouse MJ, Veit RR, Heywood RB (1992) Changes in seabird species abundance near south Georgia during a period of rapid change in sea-surface temperature. Antarct Sci 4:15-22

Jenkins GP, May HMA, Wheatley MJ, Holloway MG (1997) Comparison of fish assemblages associated with seagrass and adjacent unvegetated habitats of Port Phillip Bay and Corner Inlet, Victoria, Australia, with emphasis on commercial species. Estuar Coast Shelf Sci 44:569-588

> Jouventin P, Capdeville D, Cuenotchaillet F, Boiteau C (1994) Exploitation of pelagic resources by a nonflying seabirdsatellite tracking of the king penguin throughout the breeding cycle. Mar Ecol Prog Ser 106:11-19

Kato A, Watanuki Y, Nishiumi I, Kuroki M, Shaughnessy P, Naito Y (2000) Variation in foraging and parental behavior of King Cormorants. Auk 117:718-730

$>$ Lescroel A, Bost CA (2005) Foraging under contrasting oceanographic conditions: the gentoo penguin at Kerguelen Archipelago. Mar Ecol Prog Ser 302:245-261

Marchant S, Higgins PJ (1990) The handbook of Australian, New Zealand and Antarctic Birds, Vol 1. Part A. Oxford University Press, Melbourne

Mickelson MJ, Dann P, Cullen JM (1992) Sea temperature in Bass Strait and breeding success of the little penguin Eudyptula minor at Phillip Island, South-Eastern Australia. Emu 91:355-368

Montague TL, Cullen JM (1988) The diet of the little penguin Eudyptula minor at Phillip Island, Victoria. Emu 88:138-149

> Oedekoven CS, Ainley DG, Spear LB (2001) Variable responses of seabirds to change in marine climate: California Current, 1985-1994. Mar Ecol Prog Ser 212: 265-281

Orians GH, Pearson NE (1979) On the theory of central place foraging. In: Horn DJ, Mitchell RD, Stairs GR (eds) Analysis of ecological systems. Ohio State University Press, Columbus, p 155-177

Paiva VH, Ramos JA, Martins J, Almeida A, Carvalho A (2008) Foraging habitat selection by little terns Sternula albifrons in an estuarine lagoon system of southern 
Portugal. Ibis 150:18-31

Peck DR, Congdon BC (2005) Colony-specific foraging behaviour and co-ordinated divergence of chick development in the wedge-tailed shearwater Puffinus pacificus. Mar Ecol Prog Ser 299:289-296

Peck DR, Smithers BV, Krockenberger AK, Congdon BC (2004) Sea surface temperature constrains wedge-tailed shearwater foraging success within breeding seasons. Mar Ecol Prog Ser 281:259-266

Perriman L, Houston D, Steen H, Johannesen E (2000) Climate fluctuation effects on breeding of blue penguins (Eudyptula minor). NZ J Zool 27:261-267

Pinaud D, Cherel Y, Weimerskirch H (2005) Effect of environmental variability on habitat selection, diet, provisioning behaviour and chick growth in yellow-nosed albatrosses. Mar Ecol Prog Ser 298:295-304

Polovina JJ, Howell E, Kobayashi DR, Seki MP (2001) The transition zone chlorophyll front, a dynamic global feature defining migration and forage habitat for marine resources. Prog Oceanogr 49:469-483

Quinn GP, Keough MJ (2002) Experimental design and data analysis for biologists, Vol 1. Cambridge University Press, Cambridge

R-Development Core Team (2003) R: a language and environment for statistical computing. R Foundation for statistical computing, Vienna

Radl A, Culik BM (1999) Foraging behaviour and reproductive success in Magellanic penguins (Spheniscus magellanicus): a comparative study of two colonies in southern Chile. Mar Biol 133:381-393

Ray GC (1991) Coastal zone biodiversity patterns. Bioscience 41:490-498

Ropert-Coudert Y, Kato A, Naito Y, Cannell BL (2003) Individual diving strategies in the little penguin. Waterbirds 26:403-408

Editorial responsibility: Rory Wilson,

Swansea, UK
Sandery PA, Kampf J (2005) Winter-spring flushing of bass strait, south-eastern Australia: a numerical modelling study. Estuar Coast Shelf Sci 63:23-31

Schreer JF, Kovacs KM, Hines RJO (2001) Comparative diving patterns of pinnipeds and seabirds. Ecol Monogr 71: 137-162

Stahel C, Nicol S (1982) Temperature regulation in the little penguin, Eudyptula minor, in air and water. J Comp Physiol B 148:93-100

Takasuka A, Aoki I (2006) Environmental determinants of growth rates for larval Japanese anchovy Engraulis japonicus in different waters. Fish Oceanogr 15:139-149

Tirelli V, Borme D, Tulli F, Cigar M, Umani SF, Brandt SB (2006) Energy density of anchovy Engraulis encrasicolus L. in the Adriatic Sea. J Fish Biol 68:982-989

> Tremblay Y, Cherel Y (2000) Benthic and pelagic dives: a new foraging behaviour in rockhopper penguins. Mar Ecol Prog Ser 204:257-267

Weavers BW (1992) Seasonal foraging ranges and travels at sea of little penguins Eudyptula minor, determined by radiotracking. Emu 91:302-317

Wilson RP, Grant WS, Duffy DC (1986) Recording devices on free-ranging marine animals - does measurement affect foraging performance? Ecology 67:1091-1093

Wilson RP, Scolaro JA, Gremillet D, Kierspel MAM and others (2005) How do Magellanic penguins cope with variability in their access to prey? Ecol Monogr 75:379-401

Yen PPW, Sydeman WJ, Hyrenbach KD (2004) Marine bird and cetacean associations with bathymetric habitats and shallow-water topographies: implications for trophic transfer and conservation. J Mar Syst 50:79-99

Yorke J (2003) Diving behaviour of little penguins Eudyptula minor while foraging during incubation and chick-rearing stages at Phillip Island. Honours thesis, University of Melbourne, Melbourne

Submitted: November 11, 2007; Accepted: April 4, 2008

Proofs received from author(s): July 22, 2008 